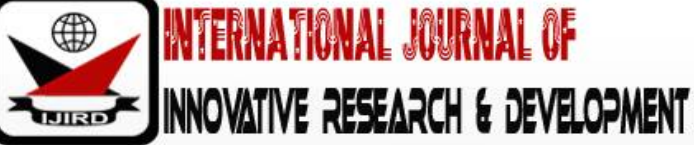

ISSN 2278 - 0211 (Online)

\section{Universal Human Rights, Indigenous Values and the Concept of Relativism}

\author{
Dr. Josephine Aladi Achor Agbonika \\ Associate Professor, Department of Law, Kogi State University, Anyigba, Kogi State, Nigeria \\ Dr. Joshua Igonoh \\ Senior Lecturer, Department of Private and Property Law, Salem University, Kogi State, Nigeria
}

\begin{abstract}
:
One emerging issue in contemporary human rights is whether it is logically correct to accept new realm of human rights as universally binding upon cultural rights arising from the moral and religious mores of every society, without more, and whether application of human rights should be relativized, at least in isolated circumstances. Discussing relativism of human rights within the framework of indigenous values, the paper took the position that a holistic application of recent realm of human rights universally in radically different societies would be counterproductive. Accordingly, the paper recommends that first and second generation rights be relativized where they develop beyond the original text of Universal Declaration of Human Rights.
\end{abstract}

Keywords: Human rights, Relativism, and Universality

\section{Introduction}

Human rights as a concept has philosophical root in the natural law School, warranting its description by Cranktson as the "twentieth century name for what has been traditionally known as natural rights, or in a more exhilarating phrase, rights of man".1 Drawing its inspiration from nature, the theory of natural law holds that there is some connection between law and the value of freedom and equality in the sense that an oppressive and arbitrary rule over human beings is incompatible with human nature, as intended by the creator. ${ }^{2}$ It was on this principle that the $17^{\text {th }}$ and $18^{\text {th }}$ centuryphilosophers like Hobbes, Rousseau, Montesque and Locke developed their concept of inalienability and inprescriptibility of human rights on the notion that human rights attach to all humans, everywhere, at all times, by virtue of their being human. ${ }^{3}$ Here it appears that the term "inprescriptibility" is only understood to mean rights that are not created or conferred in the strict sense of the word, but only legislatively endorsed.

The word "right" has been defined as that to which a person has a just and valid claim, whether it be land, a thing, or the privilege of doing something or saying something.4 Rights that are guaranteed by positive law (lex lata) are referred to as legal rights while those that are yet to receive such legal endorsement may only exist more in moral capacity. 5 This is why Oputa defined the word "right" to mean, the capacity residing in one man or group to control the actions of others

*LL.B (ABU), BL, LL.M (University of London), Ph.D ( Uni-Abuja), ACTI, ACIArb, LSM, JP, Associate Professor of Law, Faculty of Law, Kogi State University, Anyigba, Dean, College of Law, Salem University, Lokoja (on Sabbatical from 2017 to 2018); visiting Associate Professor of Law, Salem University, Lokoja from 2018 to date; Commissioner, Tax Appeal Tribunal (from 2010 to 2016); and also legal practitioner.

** Ph.D Kogi State University, Anyigba, Senior Lecturer, College of Law, Salem University, Lokoja, Kogi State.

1. Crankston, N., 'What are Human Rights?' <www1.umn.edu/ humanrts/ .../ what-are-human-rights>accessed on 10-06-2016. See also Ogbu, O.N. Human Rights Law and Practice in Nigeria (Enugu: CIDJAP Press, 1999) 3. See also Nwabueze, B.O., Constitutionalism in the Emergent States (London: C. Hurst and Co.ltd; 1973) 41; Roscoe, P., 'Philosophical Foundation of Human Rights' (UNESCO, 1986); Karel, V., International Dimensions of Human Rights (Paris: Pendone, 1981).

2. $\quad$ Ogbu op.cit., at 4.

3. Hobbes, T., 'History of the Inalienability Rights Argument'<www.abolish-human-rentals.org/hobbes>accessed on 10-06-2016; Rousseau, J., The Inalienable Rights of the Individual and

the Sovereign Will' <quadrant4.org/rousseau.html> accessed on 10-06-2016; Montesquieu, W.C., 'Inalienable Rights'<www.ellerman.org/inalienablerights/ > accessed on 10-06-2016; Locke, J., Theory of Inalienable Rights' <communityweber.edu/ .../ theory-of-inalieble-rights>accessed on 10-06-2016. 4. Hobbes, T., 'History of the Inalienability Rights Argument'<www.abolish-human-rentals.org/ hobbes >accessed on 10-06-2016; Rousseau, J., The Inalienable Rights of the Individual and the Sovereign Will' <quadrant4.org/rousseau.html> accessed on 10-06-2016; Montesquieu, W.C., 'Inalienable Rights'<www.ellerman.org/inalienable-rights/> accessed on 10-06-2016; Locke, J., 'Theory of Inalienable Rights' $<$ communityweber.edu/ .../ theory-of-inalieble-rights>accessed on 10-06-2016.

5. Oputa, C., Human Rights in the Political and Legal Culture of Nigeria (Lagos: Nigerian Law Publications Ltd; 1988) 38-39.

6. Ibid at 2.

7. $\quad$ Oputa, C., Human Rights in the Political and Legal Culture of Nigeria (Lagos: Nigerian Law Publications Ltd; 1988) 38-39.

8. Akande, J., 'Securing Individual Rights' being part of the proceedings of the Conference on Constitution and Federalism held at Unilag, Nigeria; 23-25 April, 1996. 
with the assent and assistance of the State. 6 For Akande, the word "right" means "a just claim", adding that when someone is described as having a right, he is acknowledged to be entitled to something to which he has a just claim under the law.7 Closely linked to the word "right" is the word "human" which Yerima simply defines as "pertaining to, characteristic of, or having the nature of mankind"8. From this, it is clear how human rights came to be variously defined as "the right one holds by virtue solely of being a human person... right naturally inhering in the human being"9; "those claims made by men, for themselves or on behalf of other men, supported by some theory, which concentrates on the humanity of man as a human being, a member of mankind"10; "rights and freedom which every person is entitled to enjoy possibly deriving from natural law"11; "rights one has simply because one is a human being"12; "rights which all persons everywhere and at all times equally have by virtue of being moral and rational creatures."13

Ogbu summed up human rights as rights that are:

Inherent in any human being simply because of his humanity-the birthright of all mankind. The expression human rights' in its widest connotation embraces those civil, political, economic, social, cultural, group, solidarity and developmental rights which are considered indispensable to a meaningful human existence ${ }^{14}$.

The obvious shortcoming in all these definitions is that at a glance, they give impression that all rights attaching to man as a member of mankind are enforceable in law, a summation that is impracticable because of economic and social differences of each nation state. This is why this work would rather prefer a more embracing definition of human rights in its simplest form as rights inherent in every member of mankind as endorsed by law. This is because in practical terms, only rights endorsed by the domestic laws of each nation state qualify as human rights, usually referred to in National Constitutions as "fundamental rights" because they are "guaranteed by basic or prominent law... tied to fundamental freedom"15.

Yerima put the distinction more succinctly when he said human rights arising from natural rights predate the States; they are not given by positive law nor capable of being abrogated, while fundamental human rights are guaranteed by National Constitution ${ }^{16}$. What is apparent from all these in the Nigerian scenario is that some "human rights" are entrenched in the Nigerian Constitution not in the sense that they are conferred or prescribed by the Constitution but only guaranteed by the Constitution and therefore regarded as "fundamental human rights"17. These are rights which the Supreme Court said are not just rights, belonging to the citizens but rights that have always existed even before orderliness prescribed rules for the manner they are to be sought.18 No wonder, Cicero said "It is a sin to try to alter this law, nor is it allowable to attempt to repeal any part of it and it is impossible to abolish it entirely." 19

Under international human rights instrument, these rights are basically categorized into International Covenant on Civil and Political Rights and the International Covenant on Economic, Social and Cultural Rights; ${ }^{20}$ with all their protocols. Under the Nigerian Constitution, rights endorsed under ICCPR regarded as first generation rights are adopted as enforceable fundamental human rights while those endorsed under ICESCR regarded as second generation rights are entrenched as non-justiciable rights ${ }^{21}$. While it is conceded that rights endorsed under either instrument are functionally interdependent but an attempt to reckon the second generation rights as justiciable could result in unmanageable social problem in a limited economy like Nigeria, lacking any serious productive industrial base. That is why article 2(1) of ICESCR makes its application subject to "availability of resources" of each state membership.

In any case, it must be emphasized that not all legal rights are human rights, properly so called. Having earlier defined human rights as rights naturally inhering to every member of mankind as endorsed by law, for the purpose of this paper, it is obvious that rights in contract and in tort are not human rights, more especially because human rights cannot be held by non-human juristic persons ${ }^{22}$. In this paper therefore, only human rights properly so-called are the focal point, to determine how far a form of relativism could be allowed on the ground of moral and religious values, to ensure greater effect of the human rights regime, especially in Nigeria.

9. Yerima, T., 'Appraising the Significance of the Liberal and Utilitarian Conceptions of Human Rights in the 1999 Constitution of Nigeria' Ikeja Bar Review, [2007] vol. 2, Part 1. See also Hornby, A.S., Oxford Advanced Learners Dictionary (Oxford: Oxford University Press, 1998$)$ 581.

10. Rutherford, L, and Bone, S., (eds) Osborne Concise Law Dictionary, 8th edn (London: Sweet and Maxwell, 1993) 293.

11. Donnelly, J., 'Human Rights and Human Dignity: An Analytic Critique of Non-Western Conceptions of Human Rights'. American Political Science Review. [1982] vol.76. 305.

12. Ibid.

13. Nwabueze, B., Constitutionalism in the Emergent States (London: C, Hurst \&Co; 1973) p.83 See also Ogbu, op.cit., at 114.

14. Nwabueze, op.cit, at 83.

15. Ogbu, op.cit., at 114

16. Yerima, T., op.cit. This is why Constitutional Rights like those guaranteeing life, liberty and property are presented in negative terms. See Ogbu op.cit; Gasioku, op.cit.

17. Saude v Abdullahim (1989) 4NWLR (pt.116) 387 see also Yerima, op.cit 207; Yerima prefers to refer to the rights in chapters $2 \& 4$ as human rights but distinguishing those in cap.2 as fundamental rights.

18. Ransome Kuti v Attorney-General of the Federation (1983) 2NWLR (pt.6) 211 at 230.

19. Cicero, C.F., 'Why Human Rights are called Human Rights' <science.jrank.org/ .../ Human-Rights-on-Cicero> accessed on 10-06-2016. See also Freeman, MDA (ed) Lloyd's Introduction to Jurisprudence, 17th edn, 140-141.

20. Hereinafter referred to as ICCPR and ICESCR, respectively.

21. Chapters II and IV of the Constitution of Federal Republic of Nigeria, 1999 (hereinafter referred to as the Constitution or the 1999 Constitution). This distinction is of particular interest to this research which is amongst other things calling for relativism of human rights on moral and religious grounds.

22. Yerima, T., op.cit at 188. 


\section{Concept of Universality of Human Rights}

Before the United Nations Charter, International Law did not actually recognize natural rights although there were indications in that direction. ${ }^{23}$ However, the beastly injustice perpetrated by man against man in the Second World War which resulted in growing insecurity and decline of socio-economic standard and social justice resulted in the revival of natural law in "a relativistic complexion" as "ideals that inform and inspire man-made law". ${ }^{24}$ According to Anan, ${ }^{25}$ it was the shocking revelation of the atrocities of the Second World War that brought the international community to the threshold of the realization that human rights could no longer be left to domestic jurisdictions. All the same, attempt to include a Bill of Rights in the 1945 Charter dragged on till 1948 when the United Nations General Assembly adopted the Universal Declaration of Human Rights, symbolic only and as aspiration to which member States should strive to attain. ${ }^{26}$ Indeed, the declaration itself did not purport to be more than a common standard of achievement for all Peoples and Nations or a yardstick to measure degree of respect for, and compliance with international human rights standards. ${ }^{27}$ Thus, it created a remarkable influence on subsequent domestic and international laws and policies as reflected in the reference of various bodies and instruments to the declaration. ${ }^{28}$ In any case, when the Nations shoved their ideological and political differences some eighteen years after the declaration, two instruments were passed that have opened the flood-gate of enforceable rights by the United Nations. ${ }^{29}$

While rights entrenched in the International Covenant on Civil and Political Rights are regarded as first generation rights, otherwise referred to as "negative rights", those in the International Covenant on Economic, Social and Cultural Rights are regarded as second generation rights. The third generation rights are solidarity rights which seek collective protection of group rights. ${ }^{30}$ Today, human rights activists and scholars have prevailed with the idea that whether first, second or third generation rights, they are all indivisible, interdependent and mutually enforceable. ${ }^{31}$ Indeed, the positionseems to be given a more robust outlook by the Vienna Declaration adopted by the Human Rights Conference to the effect that:

All human rights are universal, indivisible, interdependent and interrelated. The International Community must treat human rights globally in a fair and equal manner, on the same footing, and with the same emphasis. While the significance of national and regional particularities and various historical, cultural and religious backgrounds must be borne in mind, it is the duty of States, regardless of their political, economic and cultural systems, to promote and protect all human rights and fundamental freedom. 32

All the same, it is evident from this Declaration that it envisaged the need for a measure of relativism on the basis of what it described as "the significance of national and regional particularities and various historical, cultural and religious background" which the Declaration insisted must be borne in mind. It appears obvious that oversight of this leverage propelled Dwarkin to posit that if a right is granted, the society must be prepared to pay the price of giving it full effect without any attempt to curtail it for any reason, except where rights of others are at stake.33In any case, this is the philosophy behind universality of human rights whose relativism forms part of the emerging issues in this paper. In this work therefore, wherever the term universalism or universality is used, it denotes internationalization of human rights to give it effect, beyond local borders despite the principle of sanctity of sovereignty.

\section{Relativism: An Emerging Issue in Human Rights}

The word "relativism" is defined as "the belief that truth" or any other issue "is not always and generally valid but can be judged only in relation to other things (like) one's personal circumstances". ${ }^{34}$ While the naturalists argue in favour of universality of human rights, proponents of relativism stress that human rights are neither inherent nor universal but relative to each society, because they cannot be the same everywhere. ${ }^{35}$ According to Herman:

23. Ogbu, N.O., Human Rights Law and Practice in Nigeria (Enugu: CIDJAP Press: 1999) 10.

24. Ibid. at 10.

25. Kofi Anan, a one-time Secretary General of the United Nations.

26. Anan, K., The Universal Declaration of Human Rights' (1998) Vol.8 no.29 CRJ30<www.aquaac.org/ un/liberate.html>accessed on 10-062016.See also Gasiokwu, op.cit.

27. See Preamble of Universal Declaration of Human Rights 1964 (hereinafter referred to as UDHR). See also Gasioku, M.O.U., op.cit., 136; Elias, O., The Impact of Globalization of Human Rights'. <www.edmewlaw.co.uk>. accessed on 14-02-205.

28. African Charter on Human and People's Rights as an example of such reference. See Gasioku, op.cit., at 136 .

29. International Covenant on Civil and Political Rights (hereinafter referred to as ICCPR) and the International Covenant on Economic, Social and Cultural Rights, 1960 (hereinafter referred to as ICESCR).

30. Osita, op.cit. at 17.

31. The Council of Europe in tacit agreement with this position had, in its Declaration on Human Rights, Democracy and Development said "The European Community and its Member States draw particular

attention to the Universality and Indivisibility of human rights and the obligation of all States to respect them. They stress the important role of development assistance in promoting both economic, social and cultural rights as well as civil and political liberties by means of representative democratic government" See Osita, E., Study on the Right to Adequate Housing in Nigeria (Lagos: Shelter Rights Initiative, 1996) 21; Yerima, T., 'Internationalization of Human Rights: A Critical Appraisal and Comparison of the Trilogy of Documents in the UN System' Ikeja Bar Review, (2006/2007) vol.1 pts $1 \& 2$, at 25.

32. World Conference on Human Rights of 1993, UN doc. A/ CONT.157/ 23, 12th July 1993 endorsed by UN General Assembly Resolution 48/121, adopted without a vote on $20^{\text {th }}$ December, 1993.

33. Dworkin,R., Taking Rights Seriously (Oxford: Oxford Essays in Jurisprudence, 1972) 20

34. Hornby, A.S., Oxford Advanced Learners Dictionaryop.cit at 986. See also Bryan, A.G., Black's Law Dictionary, op.cit. The word “Culture” or "Cultural" will be given a more elaborate definition or clarification in chapter four of this work. 
Human rights are neither eternal truth nor supreme values... They are rooted neither in the conscience of the individual nor in God's plan of creation. They are of earth origin... a comparatively late product of the history of human society and their implementation does not lie in everybody's interest. In their essential, man's interests are not the same in any particular country under the conditions of the system of private ownership of the means of production. 36

This is why Ihonvbere said that human rights cannot be understood outside the social equation of each society adding that: It is, of course, impossible, in fact undesirable to generalize on the issue of human rights. At the same time, it is inappropriate to transpose standards of evaluation and determination of human rights from one society to the other. ${ }^{37}$

No matter the differences in perception of scholars on human rights concept, they all agree that human rights are "rights conceived as inherent or intrinsic in individuals as rational free-will creatures, not conferred by some positive law nor abrogated by positive laws"; 38 they are not claims based on parochial interests but "inherent and non-derogable with a universal application because all races, tribes and sexes enjoy them and apply to all persons without discrimination, regardless of individual status". ${ }^{39}$ They are fundamental, basic and guaranteed to every human being by virtue of their being human even where they contribute nothing to the society in which they dwell; being innate to

man's creation and, therefore, imprescriptible and inalienable.40

This, it is submitted, is the context in which the issue of universality and relativism should be discussed and not otherwise because these globally accepted definitions of human rights more aptly fit into the context of human rights as delineated in the original Covenants of Human Rights; as opposed to recent evolution of human rights that the West seeks to foist upon other parts of the world. ${ }^{41}$ Obviously, the concept of human rights has evolved generally and more specifically to subjects like women and children's rights, collective rights and then, wildly to specific value concepts that challenge the notion of human rights held by various Nations and Peoples of the world, in the immediate years after the second World War.

For instance, how the right to abortion, the right to pervert human sexuality in form of homosexuality and gender transplant, and the right to same-sex marriage, translate into human rights within the original definition of human rights, arising from the maiden covenants of the concepts is difficult to fathom. It is difficult to see how freedom to walk the streets naked or how a father and a daughter who elect to rear up children as procreative partners alone which is a common-place in America, fit into the Arab world where the tenets of Islamic law repulse against such attitude; or be reckoned as human rights in the Nigerian context where moral and religious values determine the people's notion of a good law.

Not only is it difficult to contain these issues in the context of the Nigerian values but they further widen the gap between the concept of universality of the West and the crave for relativism by other countries of the World, including Nigeria which has been resisting issues like same-sex marriage and some extreme ideals of women and children's rights as aversion to Nigerian values. ${ }^{42}$ These account for why some of the International Covenants continue to exist on paper without being ratified or domesticated by many countries. As some scholars explained, the international legal character of these covenants:

Lies in the fact that the International Conventions in which they are embodied are regarded under international law as legal instruments and precepts but the juristic basis of a right within a municipal legal system are the recognition and protection accorded the right by that State's legal system. 43

Obviously now, several nations are either unwilling to subscribe to some of the conventions and protocols or they insist on the need to relativize their application because recent evolution of human rights arising from a more liberal interpretation of what the first, second, third and fourth generation rights imply has driven human rights tenets beyond the original dreams of the founding fathers of universal human rights. Such issues, reflecting sociological values of the West and America appear to be the fortress upon which the pressure for relativism of human rights is premised.

While universality works on the preposition that certain ideas, concepts, institutions or practice validly transcend all cultural boundaries and hold true in all human societies, relativism puts variety in the centre. ${ }^{44}$ As Procee put it:

35. Ogbu, op.cit. at27.

36. Herman, K., 'Human Rights: A Battle Cry for Social Changes as a Challenge to Philosophy of Law' being a paper presented at the World Congress on Philosophy of Law and Social Philosophy in Sydney/ Canberra in 2003, 8-9.

37. IhonvbereJ.O., 'Under-development and Human Rights Violations in Africa' In: Shepherd,G.W., Jr (ed) Emerging Human Rights: The African Political Economy Context (NewYork: Greenwood Press, 1990) 56.

38. Obaseki, A.O., The Judiciary and Human Rights' in Osinbajo, Y, and Ukalu,A.(eds)Perspectives on Human Rights (Lagos: Federal Ministry of Justice, 1992) 17.

39. Oladele, O.A.B, and Ademola, K.F., 'Human Rights in a Multiculturalist World: The Myth and Reality in Continental Africa and Afro-Diaspora'Africana Law Journal. [2003] Vol.6 no.2 at51.

40. Osita, E., Human Rights in Africa: Some Selected Problems (Lagos: Nigerian Institute of International Affairs, 1984$) 3$.

41. Olusoji, E., 'The Impact of Globalization on Human Rights'.<www.cchnewlaw.co.uk>. accessed on 16-02-2015.

42. Frosbel, M., 'Obama Fights Nigeria's Anti Man-to-Man Lover Law'.<www.nairaland.com / .../ obamafights..>.accessed on 7-12-2014. Values of Asian Nations against some of these practices the West calls Human Rights is more vehement. See Chong, T., 'Asian Values and Confucian Ethics: MalaySingapore Dilemma' Journal of Contemporary Asia [2002] vol.12 no.3 <www.chong.co.za>accessed on 05-01-2016.

43. Oladele, A.B., 'Human Rights in a Multicultural World: The Myth and Reality in Continental Africa and Afro-Diaspora' op.cit at 51also at<africanajournal.org/ human-rights-in-africa >accessed on 14-7-2015. 
Relativism implies that every historical epoch and every culture has the equal right to present its perspective on the world. In principle, they all have the same value (but) there are no standard, independent of culture that proves that some perspectives are better than others. ${ }^{45}$

To core relativists, time, place, individual and cultural diversities constitute the main parameters for institutional organization of human societies, validity of ideas, values and knowledge and the idea that each culture is to be evaluated on the basis of its own values and norms of bahaviour; and not on the basis of universal standard strictly socalled. While universality certres around individual interest, relativism suggests that every society has its own moral code within whose framework individual rights ought to be measured and pursued.46 This is why they argue that any tenacious hold to universality is not only a neglect of the people's identity but a deliberate isolation of the people from their sociological background, who they are and what they are, thus making the rule of law in such society unattainable.48 This is the kind of reasoning, informing the approach of this paper on the need for relativism in the application of human rights, under the current dispensation. This could be seen from the perspective of sociological jurisprudence, that the understanding of the nature of human beings in a society determines the kind of rights that are ascribed to people in such society ${ }^{49}$ thus stressing that what constitute human rights is a function of the contextual understanding of the religious, metaphysical, epistemological, axiological, socio-economic, legal and political contexts of the construct of the human beings in the particular area ${ }^{50}$ This is the only reason that can be proffered for more indigenous model of regional Human Rights Instruments adopted by emerging Nations of the world, in the last few decades. ${ }^{51}$ It is the realization of the indispensability of this concept in human rights administration that informed concession to kafalah concept of Islamic law on care system, foster care and adoption, as a viable alternative to the English version in the original text of the UN Convention on the Rights of the child. ${ }^{52}$ As Wallace reasoned, this gesture was a frank acknowledgment of the fact that a uniform standard of "adoption is not recognized within every society" thus emphasizing the need to relativize certain so called human rights that cannot be said to be the same everywhere, on every subject. It is this kind of concession, as a deliberate policy, to cover moral and religious values as basis of each society's attitude to law, that is the basis for the call for relativism in this paper.

On this score therefore, it appears that the central questions to the debate on universality or relativism of human rights is whether it is logically correct to accept universal declaration of human rights as universally binding over other cultural rights arising from the people's moral and religious norms without more, and whether universal human rights should be holistically adopted in radically different societies, without necessarily homogenizing universality or legitimizing certain ills of radical relativism.

Only recently, the Human Rights Council adopted a resolution on the need to "Promote human rights and fundamental freedoms through a better understanding of traditional values of Humankind in conformity with International Human Right Laws"53 thus showing the anxiety of the Organization over the slow pace of impact of human rights arising from insensitivity to each people's values, in thepast. In spite of serious misinterpretation placed against this resolution by protagonists of universality, it is obvious that even the Human Rights Council is beginning to wake up to the need to create a form of relativism on ground of traditional values, especially for chequered moral and religious values of each people, if any serious result is expected from the huge investment of International Community, in promoting human rights ideals.

While it is conceded that core-traditionalists may explore this leverage negatively, it is disturbing to note that the philosophy of absolute universality has isolated human rights laws in a value-conscious society like Nigeria for too long.

44. Ibid. See also Rosado, C., 'Understanding Cultural Relativism in a Multicultural World' <http,www.rosado.net> accessed on 04-12-2015; Fayemi, A.K., 'Rethinking Personalism and Human Rights in 21st Century Africa' In Annie, E.D., ed, Reviledo l Erisel et de la Recherche Philosophiques (Aborney Calavi: Numero Special Berin, 2009) 239.

45. $\quad$ Procee, op.cit., at 47.

46. Rosado, op.cit., at 2. That is the only way right to cultural life under UDHR, Art.27(1); ICESCR, Art.15(1)(a); CEDAW, Art.13(c); Preamble, Universal Declaration of Cultural Diversity, 2001 and Art.4 of the said Declaration can be understood.

47. Harkovits, M.J., Cultural Relativism: Perspectives in Cultural Pluralism (New York; Vintage Books, 1973$) 31$.

48. Oduwole, E.O., The idea of Fundamental Human Rights in a Cultural Relative World", Journal of Philosophy and Development, [2006] Vol.8, nos.1\&2, at 6.

49. Bewaji,op.cit.,at 53.

50. $\quad$ Oladele, op.cit., at66.

51. The Asian, African and Islamic Nations now have their respective Human Rights Charter reflecting their respective cultural, moral and religious values. African charter for instance enshrines right to cultural development, duties and rights to the society, family, State and International Community including duty to the family and duty to promote African unity which are lacking in the Universal Rights Intrument.See Articles 24-29 of African Charter on Human and Peoples' Rights. Islamic Nations particularly question the open-ended rights of women as incongruent with Islamic values that form the pivot of life of every Muslim. See Oladele, op cit.,68.

52. United Nations Convention on the Rights of the Child, 1989, Art.20, paragraphs 2 and 3. 
Even in the Arab world, it is obvious that only a guided form of relativism can displace the core traditional values that have been upgraded into Islamic values over the years, despite pressure by the West and other human rights movements.

It is unfortunate that each time Nigerians or even African authors discuss the issue of relativism, they only dwell on how allowing any form of relativism will spell doom for human rights regime because as they claim, such leverage has in the past been allegedly exploited by government and those in leadership position, to rick havoc upon the weak and vulnerable in the name of culturalrelativism. ${ }^{54}$ Such critics seem however to forget how nauseating certain so-called human rights arising from European values are, to the Nigerian sense of reasonableness. It is difficult to see how Europe and America's sense of familyhood without a prominent father-figure has fared better than Nigerian value of a family with a father-figure at the helm of affairs. It is difficult to see how gender-transplant of the West and America advanced their human rights ideals or sense of decency in the society than it is in Nigeria. In 2018 alone, for instance, there were about 353 instances of indiscriminate shooting of innocent people by unprovoked gun trotters in America, an occurrence that is adverse to African values..$^{55}$ Indeed, how the moral and religious value-conscious societies in Nigeria will relate with and address a subject of gender transplant-couple or homosexual union and their adopted children is a riddle that protagonists of these new province of human rights in Nigeria are yet to address; especially having regards to moral and religious aversion of the people to such union.

It is equally important to note that every society has its own peculiar values arising from or moulded out of its own experience and going-through. In a socially and economically challenged Continent like Africa, and a country like Nigeria in particular, essence of every law should be determined, not by vain pleasure of individuals but utility-value of such right to the collective population. This is where the riddle of gender-transplant, homosexuality and same-sexmarriage pose a lot of challenges because the question is as to what these concepts add to the needs and challenges of individuals or the society in Nigeria.

In Africa, and Nigeria in particular, rights are not perceived as absolute and that is why the larger family has a say in how a member treats his wife and children. Absolute or exclusive rights-concepts in America, leading to relegation of family organogram or unlimited access to guns has not done that Nation any good, despite government efforts to manage the situation. This is why the bottom-line for determining the position of Nigerians in relation to human rights law and almost every other law is determined by their cultural values and interests. As Uhuru Kenyatta said in his joint press conference with Obama during the latter's official visit to Kenya in 2015, the immediate challenges of African Nations include the issue of housing, health, roads, shelter, enforcement of rights of women and children and how to improve infrastructural needs of the people, as a measure to make up for what Europe and America already attained, and not the issue of same-sex-marriage, homosexuality and gender-transplant which must be regarded as an abominable; and therefore a non-issue at this point of African history. ${ }^{56}$ Today, African Nations may have wars but not indiscriminate killing of innocent citizens by unprovoked gun trotters as in Europe and America. Today, Nigeria may be bedeviled by bad governance arising out of corruption but not how to combat the issue of gun-control, excessive drug-use and control, and major insecurity from outside infiltration in the magnitude of Europe and America. ${ }^{57}$

While absolute universalists of human rights resist any form of relativism in the name of abuse but a lot of them hardly remember that in Nigeria, like any other African Country, modern-day human rights remain only a weak option that attract no form of sympathy because, some of them are strictly out of tune with the people's values, thus emphasizing that only a modified form of human rights enforcement will work in Nigeria. For instance, in core Islamic communities in Nigeria, extension of human rights to freedom of women to walk nude on the streets will misrepresent the essence of human rights. ${ }^{58}$ Extension of human rights to women, including married women to date men and be patted on the buttocks publicly is an aversion to Nigerian moral and family values. Interpretation of human rights to cover freedom of Nigerian daughters to engage in an uncontrolled sex and to procure abortion at will in the name of human rights, is against our core values either as Muslims, Traditionalists or Christians, in Nigeria.59

These are values rooted in the people's moral and religious beliefs which will not succumb to the blackmail of the West and America too quickly, in the name of human rights; after all, only a few decades ago, some of the practices that Europe and America regard as human rights subjects today were not only frowned at but subject of criminality in those societies.

55. The Cairo Institute for Human Rights argued that 'such concept has been used in the Arab region to justify treating women as second class citizens'; <nazra.org/ en/2012/03/ un-human-rights> accessed on 09-07-2016; Zechenter, E.M., 'In the name of Culture: Cultural Relativism and the Abuse of the Individual <http:// www.jstor.org/stable/3630957> accessed on 09-02-2015; Hagasy, S., and Heschl, E., 'Changing Values Among Arab Youths; Example from the Arab World and Germany' <www.zmo.de/ .../ flyee.studies.22.pdf>accessed on 22-12-2015; Hagasy, S., etal 'Arab Youth Values and Identities: Impact of the Arab Upspring'. <www.iemed.org/ .../ Arabyouthvalues-Ha...> accessed on 02-12-2015; Jamal, A., and Tessler, M., 'Attitudes in the Arab World' <www-priceton.edu/ .../jamal-Tessler...> accessed on 02-12-2015

56. Jones, M., 'A Guide to Mass Shooting-353 Mass Shootings in America in 2015' <www.mother jones.com/ politics,2012/ >accessed on 04-012016. Only on $11^{\text {th }}$ June, 2016, an American born Afghan shut and killed 49 youths and injured over 50 others at a gay night club because of unlimited right to guns, which American government has not been able to control, in the name of right. $<$ www.cnn.com/2016/06/12/ US/ orlando-nightclubshooting > accessed on 14-06-2016. See similar incident against the Police in Dallas on 08-07-2016 <huffingtonpost.com/ news/ dallas?/ >accessed on 0907-2017. Indeed the spree is not only ongoing in America but now rife in Europe $\Varangle$ timelines.latimes.com/ deadliest-shootings-in-the-US/ > accessed on 21-07-2016.

57. Jonathan, E., 'Obama's Joint Press Conference with President Uhuru Kenyatta'< www.ibtimes.com/ Obama-kenya-joint-press-conference-inkenya> accessed on 04-01-2016. Such situation explains why Britain opted out of European Union in a recent referendum to safeguard its corevalues <www.bbc.co m / news/ uk-politics-32810887>accessed on 25-06-2016.

58. Branko, M., The United States and Europe Current Issues-Five Reasons Why Migration into Europe is a Problem'. $<w w w . s o c i a l e u r o p e . e u / 2015 / 06 /$ five- $>$ accessed on 04-01-2015. See also Corrupt Practices Bureau, 'Institution for Moral Edification' in Olu, O., Law and Contemporary Nigeria: Reflections (Lagos: Inspired Communication Limited, 2004) 26. 
Indeed, categorization of human rights into derogable and non-derogable, or first generation and second generation rights point to the realization that human rights are not the same everywhere and every time, regarding all circumstances. ${ }^{60}$ For instance, perception of each country on the penal philosophy of death sentence differs from place to place, notwithstanding that there are existing protocols against death penalty. ${ }^{61}$ Similarly, economic rights in the developed economy cannot be equated with developing economy of the third world where food, shelter, clothing and basic health remain a challenge. 62 This informs the mild way the preamble of African Charter tries to intermarry economic rights with political rights in an attempt to distance itself from the clear distinction in the United Nations version ${ }^{63}$ Thus, while the natural law scholars may insist that "human rights" naturally attach to every human by virtue of their being human, it must not be quickly forgotten that human rights as perceived by contemporary human rights protagonists could not have been the model envisaged by the founding fathers of universal human rights after the world war, when the UDHR and the Covenants were drafted.

Even at international law level, all systems of law are said to practically "impose certain limitations on the recognition and enforcement within their jurisdiction, of foreign institutions and laws".64 That accounts for why English Courts do not normally refer to foreign laws on issues of divorce, nullity, separation and maintenance proceedings, custody and adoption cases, admiralty damage cases and in cases where administration of foreign laws "will be extremely inconvenient, impracticable or violative of public policy".65 This accounts for Agbede's insistence that:

If the incident of a particular foreign Statute is such that its exercise within the jurisdiction would be revolting, the court may invoke public policy in order to avoid its unacceptable consequences. 66

Although this view more specifically reflects the philosophy of conflict of laws, it however properly reflects the philosophy behind a call for relativism of human rights and all other laws whose emanation is foreign to each jurisdiction, as is the case of universal human rights. Africa and Nigeria in particular have always had their own concept of rights; rooted in each locality's socio-political evolution and structure, including Africa's own model of managing confrontations, debates and conflict. Thus, what they do is to choose and adopt some political forms from Europe for integration on the indices of their own values, as an entirely new system. ${ }^{67}$ Until human rights drivers appreciate this in the light of African background and how foreign-based laws work, the so called civil society factor in human rights will not work because, it amounts to literally beating African notion of civil society and perception of universality of human rights to the background, turning Africans into subjects rather than citizens. ${ }^{6}$

\section{Summary, Conclusion and Recommendation}

This paper discussed universal human rights and the emerging issue of relativism within the context of indigenous values of each society. Looking at Law from the spectacle of sociological philosophy, the paper took the position that no Law can create meaningful impact if it is isolated from the core values of its local background; arguing that human right has no future in Africa outside the framework of domestic ideology. The paper thus recommended that the movement be relativized, to reflect each people's core values as the only measure that could arrest the present apathy of several societies in Africa against human right ideals.

\section{References}

i. Crankston, N., 'What are Human Rights?' \&lt;www1.umn.edu/ humanrts/ ../ what-are-human-rights \& gt;accessed on 10-06-2016. See also Ogbu, O.N., Human Rights Law and Practice in Nigeria (Enugu: CIDJAP Press, 1999) 3. See also Nwabueze, B.O.,

ii. Constitutionalism in the Emergent States (London: C. Hurst and Co.ltd; 1973) 41; Roscoe, P., 'Philosophical Foundation of Human Rights' (UNESCO, 1986); Karel, V.,

iii. International Dimensions of Human Rights (Paris: Pendone, 1981). Ogbu op.cit., at 4.

iv. Hobbes, T., 'History of the Inalienability Rights Argument'\& lt; www.abolish-human- rentals.org/hobbes \& gt; accessed on 10-06-2016; Rousseau, J., The Inalienable Rights of the Individual and the Sovereign Will' \&lt;quadrant4.org/ rousseau. html\&gt; accessed on 10-06-2016;

59. Imam U.S; 'A Critical Appraisal of Indecent Dressing Under the Nigerian Law' In Law Students Association: Essays in Honour of Justice Ahmed Olarenwaju Belgore (Ilorin: Al-Fattah Publications, 2010)87.

60. Okagbue, I., 'Pregnancy Termination and the Law in Nigeria'.<www.ncbi.nlm.nih.gov/ pubmed/ 2219225>accessed on 04-01-2015 See also Izunwa, M.O, and Ifemeje, S., 'Right to Life and Abortion Debate in Nigeria'. <www.ajol.info>journalhome.vol2/ 2011>accessed on 04-01-2015.

61. Derogable rights under International Human Rights Instruments are excusable rights under special circumstances. See Article 2(1), International Covenant on Economic, Social and Cultural Rights, 1966 which makes its application subject to available resources of each member State.

62. See Article 6(2), International Covenant on Political Rights in 1966.

63. Kenyatta, U., President of Kenya in Ernst, J., (ed) 'Obama's Joint Press Conference with President Uhuru Kenyatta'<www.ibtimes.com/ Obamakenya-joint-press-conference-in-kenya> accessed on 04-01-2016.

64. African Charter on Human and People's Rights, 1981

65. Agbede, I.O., Themes on Conflict of Laws (Ibadan: Shaneson Limited, 1989) at 80.

66. Ibid. $80,88,93$

67. Ibid; at 88

68. Kwadwo, A.A.,'Civil Society, Human Rights and Developments in Africa: A Critical Analysis'<www.unilorin.edu.ng/ .../ ...pdf.>accessed on 02-122015. See also Fernyhough, T., 'Human Rights in Pre-Colonial Africa' In: Ronald, C., ed; Human Rights and Governance in Africa (Florida: University of Florida Press, 1993) at42. 
v. Montesquieu, W.C., 'Inalienable Rights'\&lt;www.ellerman.org/ inalienable-rights/ \&gt; accessed on 10-06-2016; Locke, J., Theory of Inalienable Rights' \&lt;communityweber.edu/.../ theory-of-inalieble-rights\&gt; accessed on 10-06-2016.

vi. Hobbes, T., 'History of the Inalienability Rights Argument' \& lt;www.a bolish-human- rentals.org/ hobbes \& gt; accessed on 10-06-2016; Rousseau, J., The Inalienable Rights of the Individual and the Sovereign Will' \&lt;quadrant4.org/rousseau. html\&gt; accessed on 10-06- 2016; Montesquieu, W.C., 'Inalienable Rights'\&lt;www.ellerman.org/ inalienable-rights/ \&gt; accessed on 10-06-2016; Locke, J., Theory of Inalienable Rights'\&lt;communityweber.edu/ .../ theory-of-inalieble-rights\&gt; accessed on 10-06-2016.

vii. Oputa, C., Human Rights in the Political and Legal Culture of Nigeria (Lagos: Nigerian Law Publications Ltd; 1988) 38-39.Ibid at 2.

viii. Oputa, C., Human Rights in the Political and Legal Culture of Nigeria (Lagos: Nigerian Law Publications Ltd; 1988) 38-39.

ix. Akande, J., 'Securing Individual Rights' being part of the proceedings of the Conferenceon Constitution and Federalism held at Unilag, Nigeria; 23-25 April, 1996.

x. Yerima, T., 'Appraising the Significance of the Liberal and Utilitarian Conceptions ofHuman Rights in the 1999 Constitution of Nigeria' Ikeja Bar Review, [2007] vol. 2, Part See also Hornby, A.S., Oxford Advanced Learners Dictionary (Oxford: Oxford University Press, 1998) 581.

xi. Rutherford, L, and Bone,S., (eds) Osborne Concise Law Dictionary, 8 the dn (London:Sweet and Maxwell, 1993) 293.

xii. Donnelly, J., 'Human Rights and Human Dignity: An Analytic Critique of Non-Western Conceptions of Human Rights'. American Political Science Review. [1982] vol.76. 305.Ibid.

xiii. Nwabueze, B.O., Constitutionalism in the Emergent States (London: C, Hurst \&amp;Co;1973) p.83 See also Ogbu, op.cit., at 114.Nwabueze, op.cit., at 83. Ogbu, op.cit ., at 114.Yerima, T., op.cit. This is why Constitutional Rights like those guaranteeing life, liberty and property are presented in negative terms. See Ogbu op. cit; Gasioku, op.cit.

xiv. Saude v Abdullahim (1989) 4NWLR (pt.116) 387 see also Yerima, op.cit 207; Yerima prefers to refer to the rights in chapters 2\&amp;4 as human rights but distinguishing those in cap.2 as fundamental rights.

xv. Ransome Kuti v Attorney-General of the Federation (1983) 2NWLR (pt.6) 211 at 230.

xvi. Cicero, C.F., 'Why Human Rights are called Human Rights' \&lt;science.jrank.org/ .../ Human-Rights-on-Cicero\&gt; accessed on 10-06-2016. See also Freeman, MDA (ed) Lloyd's Introduction to Jurisprudence, 17 th edn, 140-141.

xvii. Hereinafter referred to as ICCPR and ICESCR, respectively.

xviii. Chapters II and IV of the Constitution of Federal Republic of Nigeria, 1999 (hereinafter referred to as the Constitution or the 1999 Constitution). This distinction is of particular interest to this research which is amongst other things calling for relativism of human rights on moral and religious grounds. Yerima, T., op.cit at 188.

xix. Ogbu, N.O., Human Rights Law and Practice in Nigeria (Enugu: CIDJAP Press: 1999)10. Ibid. at 10.

xx. Kofi Anan, a one-time Secretary General of the United Nations.

xxi. Anan, K., 'The Universal Declaration of Human Rights' (1998) Vol.8 no.29

xxii. CRJ30\&lt;www.aquaac.org/ un/ liberate. html\&gt; accessed on 10-06-2016.See also Gasiokwu, op.cit.

xxiii. See Preamble of Universal Declaration of Human Rights 1964 (hereinafter referred to as UDHR). See also Gasioku, M.O.U., op.cit., 136; Elias, O., 'The Impact of Globalization of Human Rights'. \&lt; www.edmewlaw.co.uk \& gt;. accessed on 14-02-205.

xxiv. African Charter on Human and People's Rights as an example of such reference. See Gasioku, op.cit., at 136.

xxv. International Covenant on Civil and Political Rights ( hereinafter referred to as ICCPR) and the International Covenant on Economic, Social and Cultural Rights, 1960 (hereinafter referred to as ICESCR). Osita, op.cit. at 17.

xxvi. The Council of Europe in tacit agreement with this position had, in its Declaration on Human Rights, Democracy and Development said "The European Community and its

xxvii. Member States draw particular attention to the Universality and Indivisibility of human rights and the obligation of all States to respect them. They stress the important role of development assistance in promoting both economic, social and cultural rights as well as civil and political liberties by means of representative democratic government" See Osita,

xxviii. E., Study on the Right to Adequate Housing in Nigeria (Lagos: Shelter Rights Initiative, 1996) 21; Yerima, T., Internationaliization of Human Rights: A Critical Appraisal and Comparism of the Trilogy of Documents in the UN System' Ikeja Bar Review, (2006/ 2007) vol.1 pts 1\&amp;2, at 25.

xxix. World Conference on Human Rights of 1993, UN doc. A/ CONT.157/23, 12 th July 1993 endorsed by UN General Assembly Resolution 48/121, adopted without a vote on 20 thDecember, 1993.

xxx. Dworkin, R., Taking Rights Seriously (Oxford: Oxford Essays in Jurisprudence, 1972)20.

xxxi. Hornby, A.S., Oxford Advanced Learners Dictionaryop.cit at 986. See also Bryan, A.G.,

xxxii. Black's Law Dictionary, op.cit. The word "Culture" or "Cultural" will be given a moreelaborate definition or clarification in chapter four of this work. Ogbu, op.cit. at27.

xxxiii. Herman, K., 'Human Rights: A Battle Cry for Social Changes as a Challenge toPhilosophy of Law' being a paper presented at the World Congress on Philosophy of Lawand Social Philosophy in Sydney/ Canberra in 2003, 8-9.

xxxiv. Ihonvbere, J.O., 'Under-development and Human Rights Violations in Africa' In: Shepherd, G.W., Jr (ed) Emerging Human Rights: The African Political Economy Context (New York: Greenwood Press, 1990) 56.

xxxv. Obaseki, A.O., 'The Judiciary and Human Rights' in Osinbajo, Y, and Ukalu, A., (eds) Perspectives on Human Rights (Lagos: Federal Ministry of Justice, 1992) 17. 
xxxvi. Oladele, O.A.B, and Ademola, K.F., 'Human Rights in a Multiculturalist World: The Myth and Reality in

xxxvii. Continental Africa and Afro-Diaspora'Africana Law Journal. [2003] Vol.6 no.2 at51.

xxxviii. Osita, E., Human Rights in Africa: Some Selected Problems (Lagos: Nigerian Institute of

xxxix. International Affairs, 1984) 3.

xl. Olusoji, E., The Impact of Globalization on Human Rights'.\&lt; www.cchnewlaw.co.uk \&gt;. accessed on 16-022015.

xli. Frosbel, M., 'Obama Fights Nigeria’s Anti Man-to-Man Lover Law'.\&lt; www.nairaland.com / .../ obamafights..\&gt;. Accessed on 7-12-2014. Values of Asian Nations against some of these practices the West calls Human Rights is more vehement.

xlii. See Chong, T., 'Asian Values and Confucian Ethics: Malay-Singapore Dilemma' Journal of Contemporary Asia [2002] vol.12 no.3 \&lt;www.chong.co.za\&gt; accessed on 05-01-2016.

xliii. Oladele, A.B., 'Human Rights in a Multicultural World: The Myth and Reality in

xliv. Continental Africa and Afro-Diaspora' op.cit at 51also at\&lt;africanajournal.org/ human- rights-in-africa \& gt; accessed on 14-7-2015.

xlv. Ibid. See also Rosado, C., 'Understanding Cultural Relativism in a Multicultural World' \&lt;http,www.rosado. net\&gt; accessed on 04-12-2015; Fayemi, A.K., 'Rethinking Personalism and Human Rights in 21 st Century Africa' In Annie, E.D., ed, Reviledo l Erisel et de la Recherche Philosophiques (Aborney Calavi: Numero Special Berin, 2009) 239.Procee, op.cit., at 47.

xlvi. Rosado, op.cit., at 2.That is the only way right to cultural life under UDHR, Art.27(1);

xlvii. ICESCR, Art.15(1)(a); CEDAW, Art.13(c); Preamble, Universal Declaration of Cultural

xlviii. Diversity, 2001 and Art.4 of the said Declaration can be understood.

xlix. Harkovits, M.J., Cultural Relativism: Perspectives in Cultural Pluralism (New York;

l. Vintage Books, 1973) 31.

li. Oduwole, E.O., The idea of Fundamental Human Rights in a Cultural Relative World",

lii. Journal of Philosophy and Development, [2006] Vol.8, nos.1\&amp;2, at 6.

liii. Bewaji, op. cit., at 53.Oladele, op.cit., at66.

liv. The Asian, African and Islamic Nations now have their respective Human Rights Charter reflecting their respective cultural, moral and religious values. African charter for

lv. instance enshrines right to cultural development, duties and rights to the society, family,

lvi. State and International Community including duty to the family and duty to promote

lvii. African unity which are lacking in the Universal Rights Instrument. See Articles 24-29 of

lviii. African Charter on Human and Peoples' Rights. Islamic Nations particularly question the open-ended rights of women as incongruent with Islamic values that form the pivot of life of every Muslim. See Oladele, op cit.,68.

lix. United Nations Convention on the Rights of the Child, 1989, Art.20, paragraphs 2 and 3.

lx. $\quad$ Wallace, R.M.M., International Law (5 th edn) (London: Sweet and Maxwell; 2005) 226

lxi. The 16 th Session of the Human Rights Council Resolution. \& lt;

ohchr.org\&gt;OHCHR\&gt;English\&gt;HumanRightsBodies\&gt;HRC\&gt;RegularSession\&gt;Session16\&gt; accessed on 18-04-2016. See also CRC, 1990, Art.5 relativising rights and duties of Parents. See Linus, I., Traditional Values and Human Rights in Africa'.

lxii. \&lt;saharareports.com/ 2012/ 08/ 30/ traditional-values-and-human-right-in-africa\&gt; accessed on 02-12-2015.

lxiii. The Cairo Institute for Human Rights argued that 'such concept has been used in the Arab region to justify treating women as second class citizens'; \&lt;nazra.org/ en/2012/03/ un-human-rights\&gt; accessed on 09-07-2016; Zechenter, E.M., 'In the name of Culture: Cultural Relativism and the Abuse of the Individual \&lt;http:/ / www.jstor.org/ stable/ $3630957 \& g t ;$ accessed on 09-02-2015; Hagasy, S., and Heschl,

lxiv. E., 'Changing Values Among Arab Youths; Example from the Arab World and Germany' \&lt;www.zmo.de/ .../ flyee.studies.22.pdf\&gt; accessed on 22-12-2015; Hagasy, S., etal 'Arab Youth Values and Identities: Impact of the Arab Upspring'. \& lt; www.iemed.org/ .../ Arabyouthvalues-Ha...\&gt; accessed on 02-12-2015; Jamal, A., and Tessler, M., 'Attitudes in the Arab World' \&lt;www-priceton.edu/... / jamal-Tessler...\&gt; accessed on 02-122015Jones, M., 'A Guide to Mass Shooting-353 Mass Shootings in America in 2015'

lxv. \&lt; www. Mother jones.com/ politics,2012/ \&gt; accessed on 04-01-2016. Only on 11 th June,2016, an American born Afghan shut and killed 49 youths and injured over 50 others at a gay night club because of unlimited right to guns, which American government has not been able to control, in the name of right.\&lt;www.cnn.com/2016/ 06/12/ US/ orlando-nightclub-shooting\&gt; accessed on 14-06-2016. See similar incident against the Police in Dallas on 08-07-2016 \&lt;huffingtonpost.com/ news/ dallas?/ \&gt; accessed on 09-072017.

lxvi. Indeed the spree is not only ongoing in America but now rife in Europe \&lt;timelines.latimes.com/ deadliestshootings-in-the-US/ \&gt; accessed on 21-07-2016.

lxvii. Jonathan, E., 'Obama's Joint Press Conference with President Uhuru Kenyata'\&lt; www.ibtimes.com/ Obamakenya-joint-press-conference-in-kenya\&gt; accessed on 04-01- 2016. Such situation explains why Britain opted out of European Union in a recent referendum to safeguard its core-values \& lt; www bbc.co m / news/ uk-politics32810887\&gt; accessed on 25-06-2016.

lxviii. Branko, M., The United States and Europe Current Issues-Five Reasons Why Migration into Europe is a Problem'. \&lt;www. socialeurope.eu/2015/06/ five-\&gt; accessed on 04-01- 2015. See also Corrupt Practices Bureau, 
'Institution for Moral Edification' in Olu, O., Law and Contemporary Nigeria: Reflections (Lagos: Inspired Communication Limited, 2004) 26.

lxix. Imam U.S; 'A Critical Appraisal of Indecent Dressing Under the Nigerian Law' In Law Students Association: Essays in Honour of Justice Ahmed Olarenwaju Belgore (Ilorin:Al-Fattah Publications, 2010)87.

lxx. Okagbue, I., 'Pregnancy Termination and the Law in Nigeria'. \&lt; www.ncbi.nlm.nih.gov/ pubmed/ 2219225\&gt; accessed on 04-01-2015 See also Izunwa, M.O, and Ifemeje, S.,

'Right to Life and Abortion Debate in Nigeria'. \&lt;www.ajol.info\&gt;journalhome.vol2/ 2011 \&gt; accessed on 0401-2015.

lxxi. Derogable rights under International Human Rights Instruments are excusable rights under special circumstances. See Article 2(1), International Covenant on Economic,

lxxii. Social and Cultural Rights, 1966 which makes its application subject to available resources of each member State. See Article 6(2), International Covenant on Political Rights in 1966.

lxxiii. Kenyata, U., President of Kenya in Ernst, J., (ed) 'Obama's Joint Press Conference With President Uhuru Kenyata'\&lt; www.ibtimes.com/ Obama-kenya-joint-press-conference-in kenya\&gt; accessed on 04-01-2016.

lxxiv. African Charter on Human and People's Rights, 1981.

lxxv. Agbede, I.O., Themes on Conflict of Laws (Ibadan: Shaneson Limited, 1989) at 80.Ibid.80,88,93.Ibid; at 88 Kwadwo, A.A.',Civil Society, Human Rights and Developments in Africa: A Critical

lxxvi. Analysis'\&lt;www.unilorin.edu.ng/ .../ ...pdf.\&gt; accessed on 02-12-2015. See also Fernyhough, T., 'Human Rights in Pre-Colonial Africa' In: Ronald, C., ed; Human Rights and Governance in Africa (Florida: University of Florida Press, 1993) at 42. 